International Review of Social History 45 (2000), pp. I-23

(C) 2000 Internationaal Instituut voor Sociale Geschiedenis

\title{
Artisans and Work in a Barcelona Cotton Factory $(\mathrm{I} 770-\mathrm{I} 8 \mathrm{I} 6)^{*}$
}

\author{
Marta Vicente
}

\begin{abstract}
Summary: The present article analyzes the crucial impact that artisan forms of organizing work had in the production of early cotton factories. By examining the case of the Sirés factory in Barcelona, this article argues that dividing work by gender and age and working with relatives, all traditional practices in an artisan shop, allowed eighteenth-century factory owners to face the challenges that production posed. The example of the Sirés factory also offers a picture of early industrialization that challenges the long-standing argument that artisan and factory forms of production were antagonistic. Factory owners organized their production and work in ways that replicated the way artisans had long produced and worked in their shops. Moreover, in shops and factories alike, production depended not just on the work of individuals, but also on that of their relatives. Parents and children, husbands and wives - all brought the flexibility of traditional artisan forms of organizing work to the new factories.
\end{abstract}

\section{INTRODUCTION}

In the late seventeenth century, a new type of cotton cloth, calico, revolutionized the European fashion world. ${ }^{\mathrm{I}}$ The attractiveness of calico came from the combination of the lightweight cotton fabric and its characteristic designs, which were printed in bright colors that did not fade after washing. All over Europe, in cities such as London, Manchester, Paris, and Amsterdam, shopkeepers stored yards of calico for the growing number of consumers of this fashionable fabric. Merchants in those cities initially imported calicoes from India but, by the early eighteenth century, they were already buying them from European manufacturers, who soon became the main providers for European markets and even the American colonies. By I760,

* Early versions of this article were presented at the Seminar on Family Enterprise and Small Commodity Production at the University of Delaware in April 1994, and the ESTER seminar on Gender Division of Labor at Bertinoro (Italy) in October 1996. I would like to thank the participants and organizers of these seminars, specially the comments of Angélique Janssens, Tamara Hareven, Jane Humphries and Carlo Poni. I am also grateful to Luis Corteguera and Carolyn Nelson for their help. Finally, I wish to thank the Arxiu Històric de la Ciutat de Barcelona and the Arxiu de la Corona d'Aragó for permission to reproduce the illustrations here included.

I. The word calico derives from Calicut in south-west India; see Judith Jerde, Encyclopedia of Textiles (New York, 1992), p. 23. 
there were more than seventy calico factories in France and Great Britain; in 1785 , the number increased to more than $225 .{ }^{2}$ The growing consumption of calicoes was the reason behind this increase. Throughout the eighteenth century, more and more Europeans made calico clothing part of their everyday lives. Artisans, merchants, and peasants alike wore calico and used this fabric to adorn their houses and cover their beds. ${ }^{3}$

In Spain, a similar calico craze was taking place. By I740, shopkeepers in Catalonia filled up their shelves with thousands of yards of all kinds of flowered and colorful calicoes, from the inexpensive fustians to the luxurious and soft muslinets, made of a mixture of cotton and silk. ${ }^{4}$ Most of these were imported. Although the first calico factory in the Iberian peninsula dated from 1736, it was only by the second half of the century that Catalan manufacturers produced most of the calicoes Spaniards consumed. Such industrial growth made Spanish journalist Francisco Mariano Nifo praise Catalonia as the "little England" in the Iberian peninsula. ' Leading this astonishing industrial expansion in Catalonia was Barcelona, with about eighty calico factories of all sizes in $1784 .{ }^{6}$ In this year alone, the city's factory owners manufactured about seven million meters of printed calicoes. This was a substantial quantity, considering that factory owners in all of Britain produced only an annual average of four million meters in the same period. ${ }^{7}$

Merchants and artisans formed the majority of Barcelona's factory owners who manufactured calicoes in the second half of the eighteenth century. These factory owners manufactured the cloth themselves or, more commonly, administered the factory while entrusting the production process to a manager, or fabricant. The fabricant was an experienced worker who knew how to prepare the mordant, the chemical mixture that, combined with the dye, gave calico its characteristic colors. He also controlled the production process and was in charge of hiring or dismissing workers. Fabricants were usually local artisans who had learned the printing techniques from foreign experts. Most workers who wound, warped, wove, bleached, and dyed calicoes in factories were also Barcelona artisans. ${ }^{8}$

2. Stanley D. Chapman and Serge Chassagne, European Textile Printers in the Eighteenth Century: A Study of Peel and Oberkampf (London, I98I), p. 8. Indian calicoes were usually painted with fine pencils, whereas European ones were printed with engraved blocks.

3. Chandra Mukerji, From Graven Images: Patterns of Modern Materialism (New York, 1983), pp. I66-209.

4. James K.J. Thomson, A Distinctive Industrialization: Cotton in Barcelona, $1728-1832$ (Cambridge etc., I992), pp. 64-66.

5. Francisco Mariano Nifo, Estafeta de Londres, 2 vols (Madrid, I770), 2, p. 44. For information about Nifo's writings see Ernest Lluch, La Catalunya vençuda del segle XVIII: Foscors i clarors de la Il. lustració (Barcelona, I996), pp. 155-159.

6. Thomson, Distinctive Industrialization, pp. I83-196.

7. Idem, "The Catalan Calico-Printing Industry Compared Internationally", Societat Catalana d'Economia, 7 (1989), pp. 72-95, 78.

8. Before the $178 \mathrm{os}$, factory owners imported most of the spun thread they needed from Maltese merchants. By 1785 , factory owners had introduced technological changes that allowed them to 
Although factory owners had access to an available workforce among local artisans, they still had to face an important challenge in the production of calicoes. Factory owners had to adapt a very large but unstable workforce to the variable tempo of production. On the one hand, the calico production process was slow, with many variations. The entire process could last anything from four weeks to twelve or more, depending on the quality of the cloth, the complexity of the designs, and most of all, on the weather conditions. For instance, though the printing and dyeing of calicoes could last from two to three weeks in the summer, these activities could take months during the rainy season, which lasted from November to March. On the other hand, factory owners needed workers to adapt to the rhythm of production. At times, employees had to work intensely; at other times, they only had to work a few hours during the day. ${ }^{9}$ This represented a challenge for factory owners, since in addition to the variable workloads, the workforce tended to be unstable. Workers would leave their employers to take up work at other factories, to attend to family needs, or, as in the case of weaver Juan Ribas, "to take the [mineral] waters and amuse himself" . ${ }^{\text {Io }}$ Any unexpected changes in the workforce would affect the flow of production in the factory and ultimately the ability of the factory owner to serve clients on time.

Juggling production activities, the workforce, the weather, and the provision of raw materials challenged calico factory owners to find the most efficient ways of organizing their production and their workforce. Factory owners sought the solution to this challenge by adopting the organization of work that was traditional among artisans. In this article, I will examine how factory owner Joan Baptista Sirés addressed this challenge by organizing his labor force in ways that resembled the division of work by gender and age in artisan shops. In general, Sirés had men working in the best-paid tasks - those Sirés considered crucial for the quality of the final product while he hired women and children to carry out mostly preparatory and assisting duties. II Sirés also tended to hire workers who had relatives who worked in the factory. He had some of his employees live at the factory

use locally produced thread and thus be less dependent on Maltese merchants; see Thomson, Distinctive Industrialization, pp. 235-267.

9. Sirés had to send all, or some, of his weavers home when the factory was not adequately stocked with cotton thread. Bad weather, production cycles, and changes in demand caused factory production and its workforce to vary constantly. For similar work routines in other factories see Chapman and Chassagne, European Textile Printers, pp. I7I-I82, and Leonard N. Rosenband, "Hiring and Firing at the Montgolfier Paper Mill", in Thomas M. Safley and Leonard N. Rosenband (eds), Artisans and Proletarians, I500-I800 (Ithaca, NY, etc., I993), pp. 225-240.

Iо. Arxiu Històric de la Ciutat de Barcelona [hereafter, AHCB]: Arxiu del Veguer, XXXVII-IOzo bis, I797.

II. Although Sirés hired children of both sexes, he listed girls together with women workers, whereas he recorded boys' wages in their own separate section. Girls usually worked as winders with their female relatives. Boys under fourteen assisted adult male workers in the factory building or in the bleaching meadows. 
and allowed workers to train their own family members and have relatives substitute for them in their workplace. All these were traditional forms of organizing work and production in the artisan workshop, strategies that Sirés hoped would help workers to adapt more easily to the variable production process.

In this article, I also want to evaluate how the artisan organization of work in large calico factories points to a relationship between artisans and industrialization that was complementary rather than conflictive. Many historians and economists have agreed that industrialization brought about a form of production opposed to the traditional artisan production based on the skilled handicraft work of guild-regulated family workshops. Accordingly, artisan production became obsolete in the industrial society, which required complex technology, mass production, and large amounts of capital. ${ }^{12}$ It has been only in the past few years that some scholars have rethought the relationship between artisan production and industrialization as being mutually complementary. This recent literature has demonstrated that artisans were able to contribute their own forms of production and organization of work to industrialization. ${ }^{13}$ The case of the Sirés factory is one example of how, by replicating long-standing traditions of the artisan home and adapting them to the needs of a new industry, early factory owners made production possible.

\section{ARTISAN WORK IN A CALICO FACTORY: THE SIRÉS FACTORY (1770-1816)}

In 1770 , apothecary Joan Baptista Sirés and veil makers Josep Aymar and Francesc Fraginals established the Sirés factory on carrer Trentaclaus in the southern part of Barcelona known as the Raval. ${ }^{\mathrm{I4}}$

I2. See, for example, Rondo E. Cameron, Banking in the Early Stages of Industrialization: A Study in Comparative Economic History (Oxford etc., 1967), pp. I6-59; N.F.R. Crafts, British Economic Growth During the Industrial Revolution (Oxford, 1985), pp. I-8; David Landes, The Unbound Prometheus: Technological Change and Industrial Development in Western Europe from 1750 to the Present (Cambridge etc., 1969), pp. I-40; W.W. Rostow, The Process of Economic Growth (New York etc., 1952), pp. 307-331.

13. See, among others, Maxine Berg, The Age of Manufactures, I700-1820: Industry, Innovation and Work in Britain, 2nd edn (Oxford etc., 1994), pp. 169-280; Maxine Berg, "Factories, Workshops and Industrial Organization", in R. Floud and D. McCloskey (eds), The Economic History of Britain since I700, I (Cambridge etc., 1994), pp. I23-I50; Maxine Berg and Pat Hudson, "Rehabilitating the Industrial Revolution", The Economic History Review, 45 (1992), pp. 24-50; Michael J. Piore and Charles F. Sabel, The Second Industrial Divide: Possibilities for Prosperity (New York, I984), pp. 3-I8; Charles F. Sabel and Jonathan Zeitlin, "Historical Alternatives to Mass Production: Politics, Markets and Technology in Nineteenth-Century Industrialization", Past and Present, I08 (1985), pp. I38-I44; Charles F. Sabel and Jonathan Zeitlin, "Stories, Strategies, Structures: Rethinking Historical Alternatives to Mass Production", in Charles F. Sabel and Jonathan Zeitlin, World of Possibilities: Flexibility and Mass Production in Western Industrialization (Cambridge, MA etc., 1997), pp. I-33.

I4. For a plan of the factory building and a map of one of the factory's bleaching meadows; see Figures I and 2. 


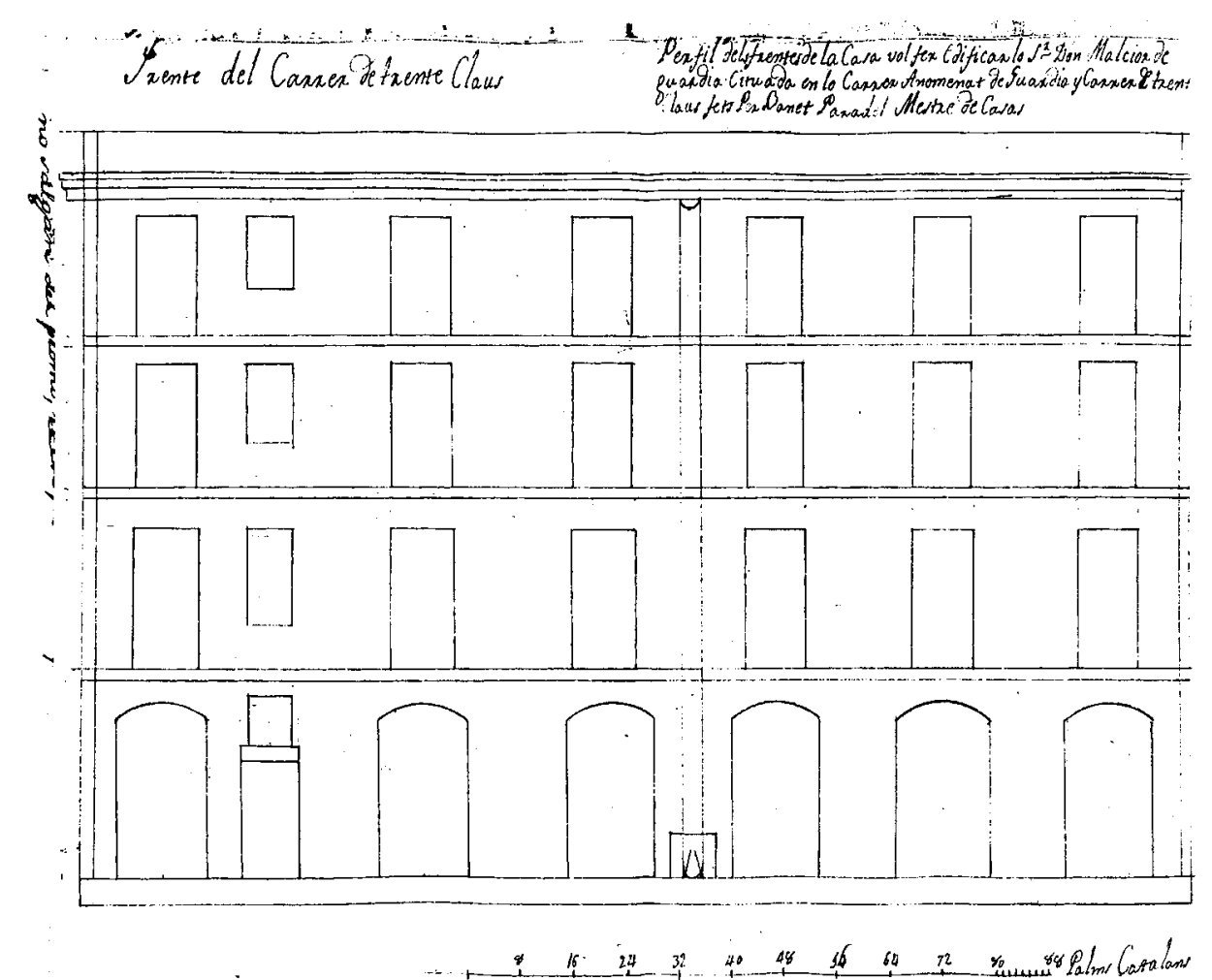

Figure I. I803 plan of the renovation of the Melchior Guàrdia building on carrer Trentaclaus. Since Sirés rented a Guàrdia building on carrer Trentaclaus, this may have been the Sirés factory. AHCB: Obreria, capsa 68, n. $15,1803$. 


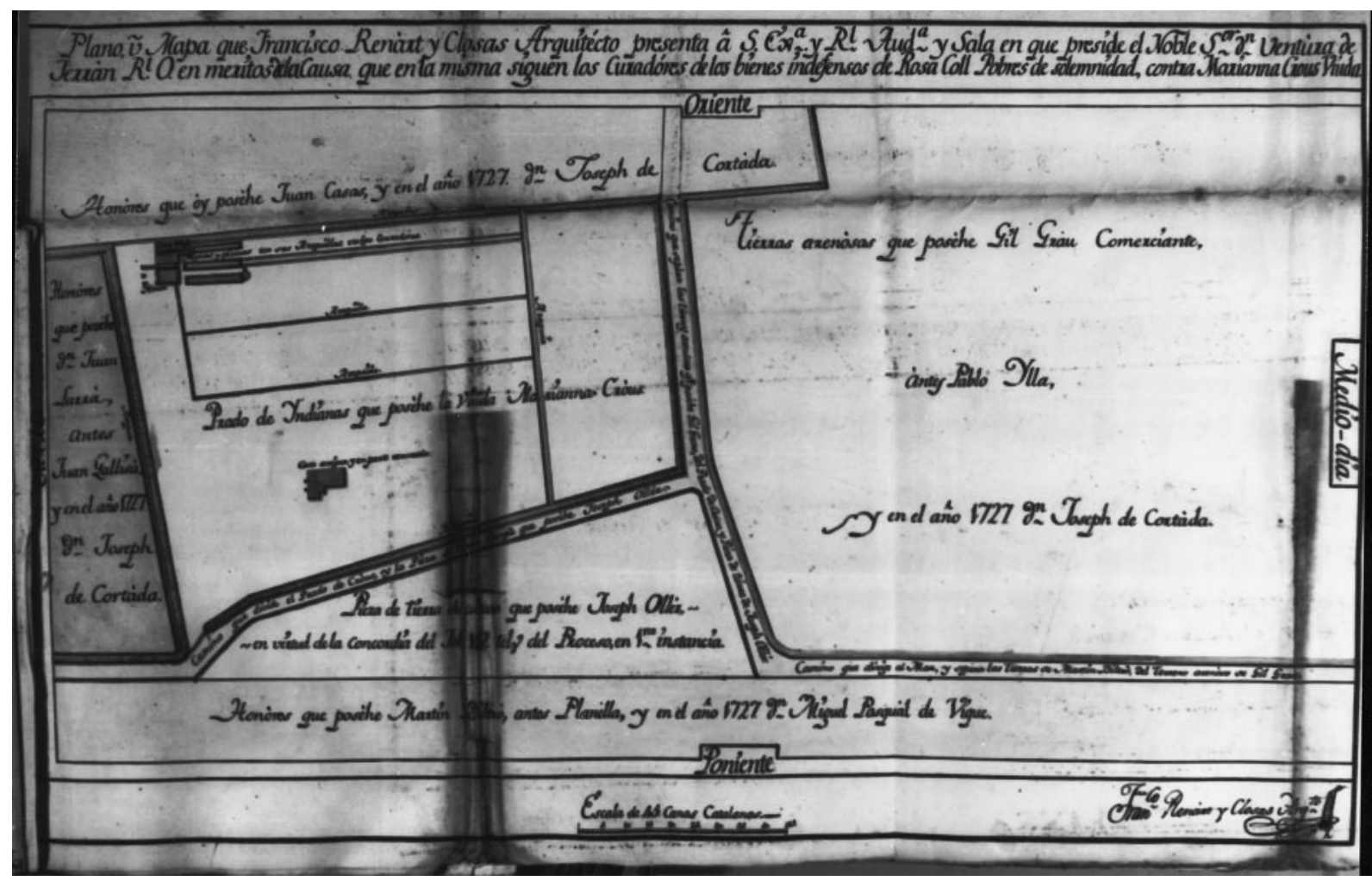

Figure 2. Plan of two Barcelona bleaching meadows. The large quadrangle left of the center line demarcates the widow Marianna Crous's bleaching meadow, which Sirés rented in the I780s. It was 7,863 square meters, and it had an irrigation channel, a water wheel, a boiler and a small house for the workers.

ACA: Mapas y Planos, MP-62o Sant Adrià de Besos [I795] Prado de indianas de Mariana Crous y terrenos circundantes. 


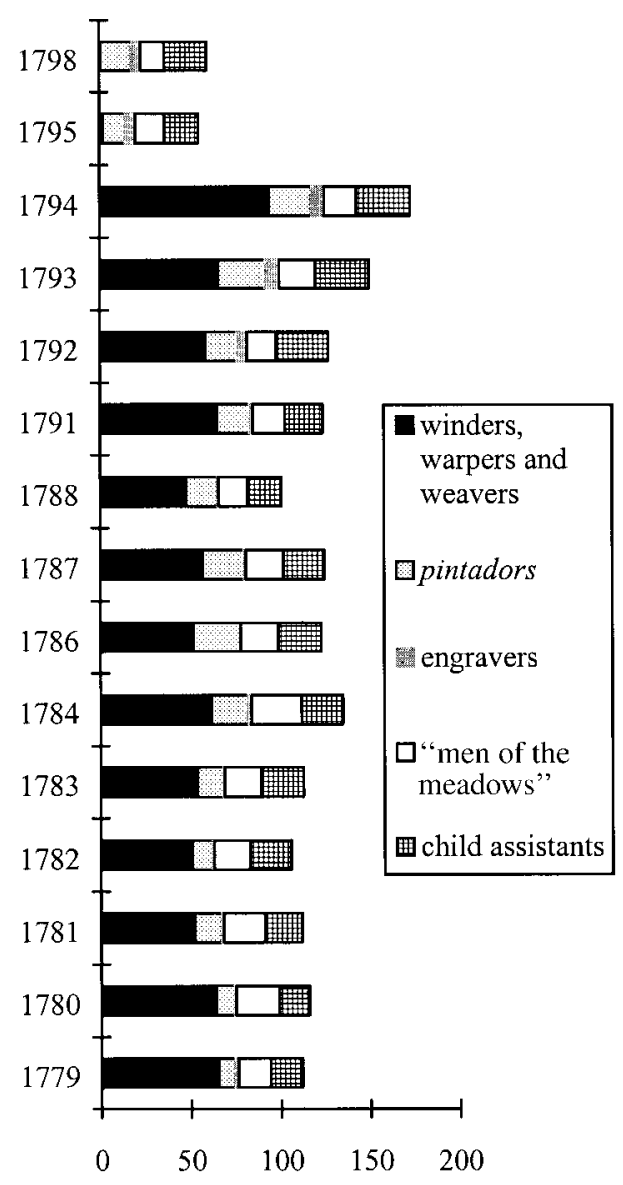

Figure 3. Workers of the factory, 1779-1798. $A H C B$ : FC, B-24I through B-258.

Compared with the city's other factories, it was a large firm. It had twentyfour looms, nineteen printing tables, and a workforce that ranged between 60 and 150 men, women, and child assistants. ${ }^{15}$

Aymar, the smallest investor in the association, was the factory's fabricant, in charge of making mordant and dyes for the calicoes. As was customary among fabricants, Aymar was also responsible for hiring new workers and supervising the foremen, who in turn supervised the workers. Fraginals, as director of textiles, supervised the sale and distribution of calicoes to clients. Sirés, the largest investor, acted as the factory's administrator. In this

15. The three associates united with the Alegre and Gibert Company. The latter, however, remained a "silent partner" in the Sirés factory. 
capacity, he contacted clients and dealt with the brokers and merchants from whom the factory purchased dyes, raw cotton, and yarn on credit. Sirés also kept the factory's account books with the assistance of a journeyman. In 1785, Fraginals and Aymar brought Sirés to court, alleging that he had failed to pay them their share of the factory's profits. Sirés lost the case but in I786, with the lawsuit over, he was finally able to run the factory on his own.

The Sirés factory is an example of the many calico factories that successfully produced the cloth during the second half of the eighteenth century in Barcelona. In the late I770s and early I780s, the Sirés factory prospered, like many others, at a rapid pace. Its sales increased twenty-seven per cent between 1770-I77I and 1775, and twenty-five per cent between I775 and 1782. The next five years recorded similar growth. Total production of calicoes in Barcelona during this decade increased on the order of 185 per cent from 1770 to $1785 .{ }^{16}$ The Sirés factory benefited from the demand that fueled the expansion of the industry during the I780s. But Sirés was not just lucky to be doing business in good times; his skills as administrator and manager helped his factory succeed where others failed. His success was grounded in his factory's ability not only to produce high-quality goods but also to satisfy clients' demands. Increasingly, clients wrote to Sirés directly, requesting a particular design, specifying the quality and quantity of calicoes they wanted to purchase, and indicating precisely when delivery was needed.

To please clients, produce with maximum efficiency, and constantly adapt production to the new requirements, Sirés needed to have absolute control over the workforce to adapt the latter to demand and changes in the weather. Each Monday morning, Sirés, his fabricant, and the two foremen considered weather conditions, production cycles, and swings in the demand for calicoes to decide how much work they would assign to workers in each factory room and in the bleaching meadows. On a sunny day in the busy summer season Sirés might have his women spinners and winders as well as his warpers and weavers work as many as twelve hours a day. In December, when days were short and fabrics would take much longer to dry outdoors, Sirés might close the winders' and weavers' rooms and send those workers home. Likewise, if printers, known as pintadors, and workers in the bleaching meadows, known as "men of the meadows", had too many cloths to print and dye, Sirés would ask winders and weavers to work less. But if Sirés received many orders for calicoes, he would give more work to all his employees and might even hire additional temporary ones. If demand fell, he might decide to shut down the winding and weaving sections and focus on printing and dyeing.

16. For the total production of calicoes in Barcelona, see Alejandro Sánchez, "La era de la manufactura algodonera en Barcelona, I736-I839", Estudios de historia social, 48/49 (1989), pp. 65-II3, 92. 


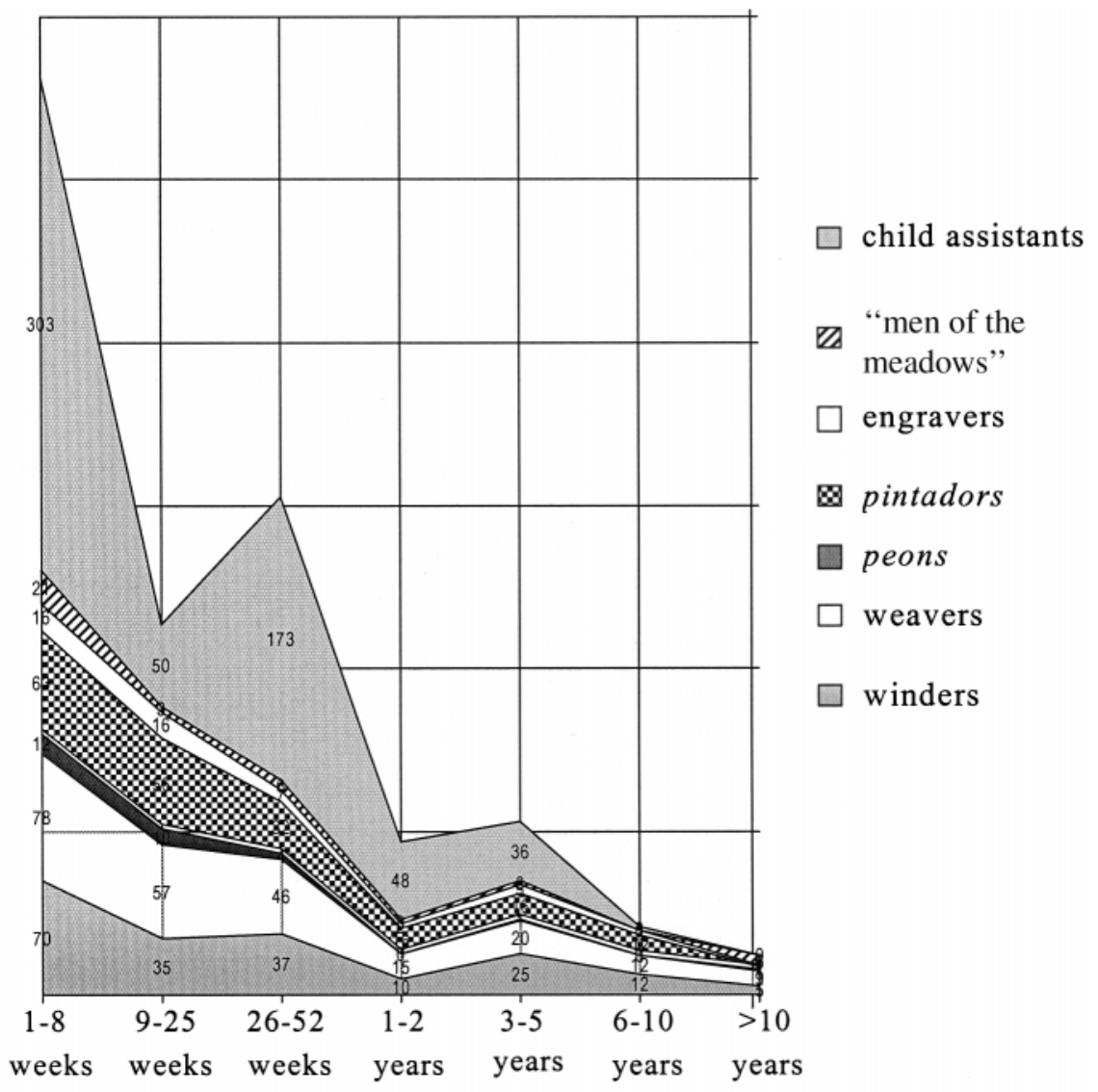

Time spent in the factory

Figure 4. Workers and time spent in the factory, 1770-1798. $A H C B, F C, B-24 I$ through $B-258$.

\section{INSTABILITY OF THE SIRÉS WORKFORCE}

In matching the number of employees to the changing tempo of production, Sirés had to contend with a very unstable workforce.

It was not unusual for workers to leave their factory jobs with only a few days' notice to take up jobs in other factories that offered them higher salaries or better working conditions. During the booming I770s and I780s, there was plenty of work in the many factories that sprang up in the city to meet an apparently insatiable demand for calicoes. In fact, Sirés's books of salaries for these two decades report several cases of workers walking out on him without giving notice. The Royal Spinning Company, an association of factory owners who supplied its members with local cotton thread, 
acknowledged the workers' lack of discipline and insubordination as general problems that affected most Barcelona calico factories. Such lack of discipline translated into a continuously unstable workforce. In 1785 , because of the complaints of factory owners about the insubordination of their workforce, the Spinning Company issued a report in which it stated: "Nowadays you will rarely find among our workers one who being admitted in a factory [...] has not [already] been in all factories in the city. What better proof of their pranks? What better sign of their problems? ${ }^{\text {'17 }}$ Historian Pedro M. Antón has confirmed the tendency of workers to move from job to job. According to Antón, at least in large factories, "the coming and going of workers was constant: each week a worker was leaving while another was coming". He found that about seventy per cent of workers stayed in a factory for less than a year, whereas those who stayed more than one year were in the minority. ${ }^{18}$

However, for the Spinning Company, the problem was not so much that workers left the factories but that they did so when they pleased, without giving advance notice to their employers. This lack of courtesy and discipline threatened the authority that factory owners had over workers and thus jeopardized the factory's entire production. According to the Spinning Company's report, calico workers routinely imposed their wills "on their masters with proud despotism, working how and when they pleased". ${ }^{\text {I9 }}$ Consequently, the report continued, "the owner who encounters fidelity and good behavior in a worker continues to employ him at all cost; if he decides to let him go, it is only because he cannot bear his [the worker's] faults". ${ }^{20}$

Sirés encountered this situation more than once. In I783, Salvador Dulzet, who entered Sirés's factory in September 1779 as an assistant to the foreman of the pintadors "to take care of all he can in the factory", suddenly quit. He wanted higher pay, and on Io April I783, with only minimal notice, he left the factory "in order to work for a certain Senyor Colom in his business as a tailor". ${ }^{21}$ Another worker who abandoned Sirés in 1783 was Llorens Roger, a "man of the meadows". He began working for Sirés in I779, but in March 1783 - like Dulzet, with virtually no notice - he left Sirés in order

17. Biblioteca de Catalunya [hereafter, BC]: Junta de Comerç [hereafter, JC], lligall 51, capsa 68, n. I6: Report 30 September 1785.

18. Pedro M. Antón, "Salarios en las fábricas de indianas de Barcelona en el último tercio del siglo XVIII" (Licentiate thesis, Universitat de Barcelona, 1972), p. 28. This was also a common problem for calico factory owners in other European cities; see Pierre Caspard, "The Calico Painters of Estavayer: Employers' Strategies Toward the Market for Women's Labor", in Daryl Hafter (ed.), European Women and Preindustrial Craft (Bloomington, IN, etc. 1995), p. II2; Chapman and Chassagne, European Textile Printers, pp. I71-182.

I9. BC: JC, lligall 5I, capsa 68, n. I6: Report, 30 September 1785.

2o. Ibid.

2I. AHCB: Fons Comercial [hereafter, FC], B-26I, fo. 2: Account books of the Sirés factory [hereafter, Account books], I783. 


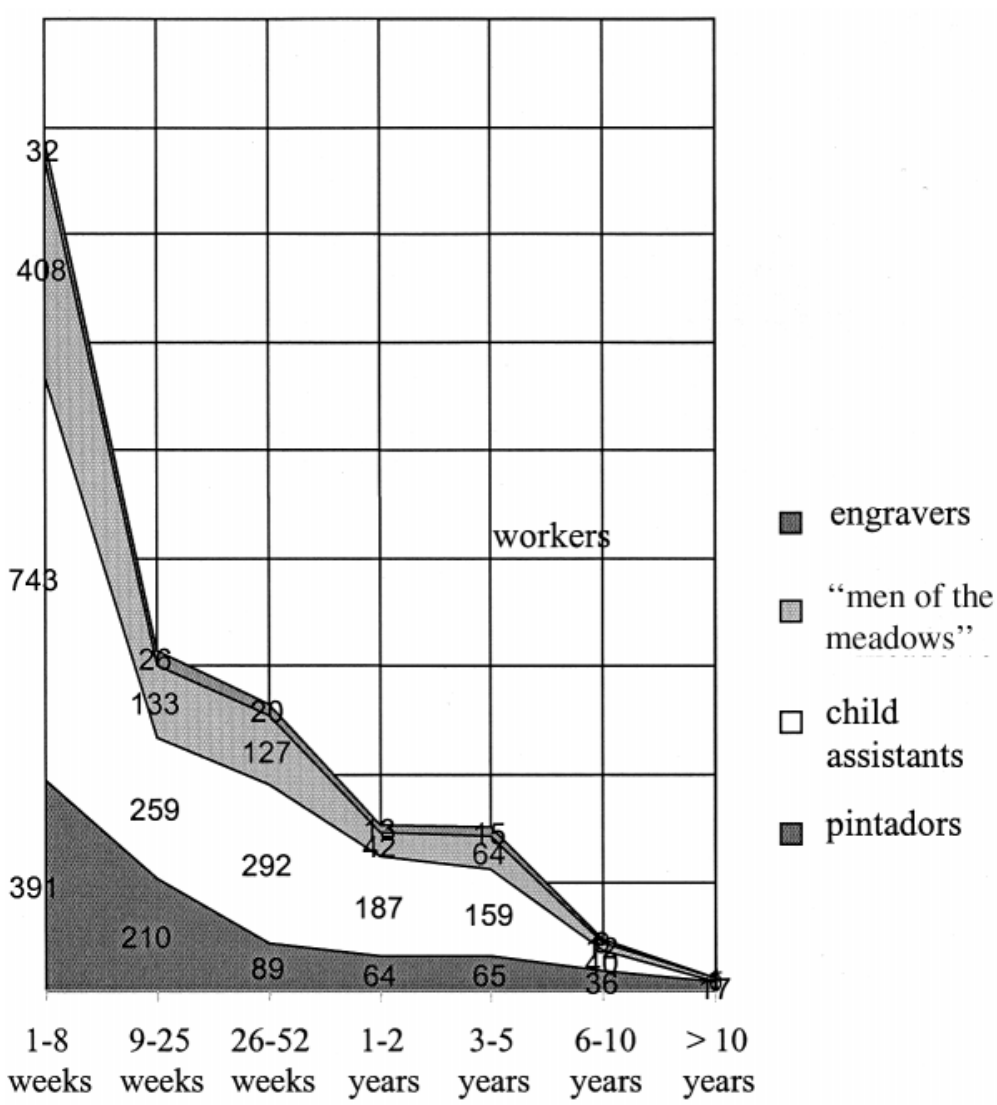

Time spent in a factory

Figure 5. Barcelona workers and average time spent in a factory.

Graph elaborated from information in Pedro M. Antón, "Salarios en las fábricas".

to work for Fèlix Valls and Josep Sarrellach, who had together established a new calico factory in Barcelona. ${ }^{22}$ A similar situation occurred the following year. Another of Sirés's key workers, foreman Salvador Goday, left the factory without notice. Sirés recorded Goday's departure in the factory's account book by noting that Goday left because another factory offered him "a bigger salary and he could not let it go" ${ }^{23}$ Goday, a veil maker from the northern coastal town of Canet, had come to the factory in 1779. As foreman of Sirés's weavers, he earned the high salary of 200 lliures annually.

Although the previous examples involved skilled workers such as foremen

22. Ibid.

23. AHCB: FC, B-262, 30 April I784, fo. I: Account books, 1784 . 
and their assistants, Sirés regularly contended with problems involving all kinds of workers. As Figure 4 shows, from 1770 to 1798 , the majority of Sirés's workers spent only a few months in the factory. About sixty per cent of the factory's entire workforce stayed for less than a year. About twentyfive per cent of all the workers stayed between one and five years, and only fifteen per cent spent more than five years working in the factory (Figure 4).

The unstable workforce caused major problems, such as production delays, for Sirés. But he was not the only factory owner to confront this situation, as Pedro M. Antón's study of large calico factories in Barcelona reveals (Figure 5). Mobility of the workforce was the price Sirés had to pay to do business; all of his workers tended to stay for only brief periods of time. However, there were some differences in mobility, depending on the skill level of the workers. For instance, highly skilled workers, such as "men of the meadows" and pintadors, generally moved around more than weavers and winders. On average, women winders stayed in the factory for about three years, about two years longer than the average for male workers. On the whole, however, instability rather than stability characterized Sirés's workforce as workers seeking better pay, better working conditions, or some combination of the two, shuttled regularly among different jobs at different factories. Sometimes workers might also leave Sirés's factory because their families needed them to work at home in the workshop or to take care of an infant or a sick relative. In other words, changing family needs, competition for workers from other factories, and individual expectations sometimes made it hard for owners to secure a reliable workforce.

\section{DIVISION OF WORK IN THE SIRÉS FACTORY}

Sirés hired male artisans, such as cotton, wool, silk, and linen weavers and dyers, lapidaries, and gunsmiths, who knew how to weave cotton cloths, engrave calico blocks, and print and dye calicoes. He also hired female artisans who spun, wound, and warped cotton thread in the factory. However, although Sirés could tap into a trained and ready artisan workforce, he still faced the challenge of adapting it to the variable tempo of his production process. He met this challenge by assigning different tasks to different types of workers.

In general, Sirés replicated in his factory the traditional gender and age division of labor in artisan shops in Barcelona and elsewhere in Europe. ${ }^{24}$

\footnotetext{
24. For the artisan organization of work in Barcelona, see Pierrre Bonnassie, La organización del trabajo en Barcelona a fines del siglo XV (Barcelona, 1975), pp. 65-120; Antonio de Capmany y Montpalau, "Discurso económico-político en defensa del trabajo mecánico de los menestrales", in E. Giralt y Raventós (ed.), Memorias históricas sobre la marina, comercio y artes de la antigua ciudad de Barcelona, 3 vols (Barcelona, 1963), 2-2, pp. 1067-1094; Pedro Molas Ribalta, Los gremios barceloneses del siglo XVIII: La estructura corporativa ante el comienzo de la Revolución Industrial (Madrid, I970), pp. 70-I29.

For artisans in other European cities; see, among others, James R. Farr, "Cultural Analysis and
} 
Typically, the male master and his male journeymen worked at the main activities of a trade - that is to say, in those tasks that resulted in the most valuable products. To perform these tasks, adult male artisans had to go through long years of training and experience: at least three to five years as apprentices under a master's supervision and a few more years as journeymen before guild officers examined and granted them the title of master. ${ }^{25}$ The master's wife, daughters, and young sons would usually take up duties that either supplied or prepared the materials necessary for the master's work - whether carding wool, spinning thread, carrying or sorting raw materials. ${ }^{26}$

In the factory, Sirés assigned men tasks that were better paid and were central to the production of calicoes, while he assigned women and child assistants work in low-paying tasks usually dealing with the preparation of the materials or assisting the adult male workers. Sirés treated the work performed by most male workers as if it were indispensable and regular; he thus subjected it to fewer changes and paid a salary for it (Figure 6). In contrast, he treated the work of women and child assistants as dispensable and variable, subjecting it to constant changes and paying by the piece or paying a very low salary (Figure 7 ). ${ }^{27}$ In assigning men the least variable tasks and women and child assistants the most variable tasks, this factory owner reduced his labor costs. Women workers paid by the piece did not have to stay idle in the factory during periods of low production, as they would have to be if paid a fixed weekly salary. Likewise, hiring children allowed Sirés to pay them very small salaries for assisting workers with various tasks in the factory.

Because Sirés decided on a weekly basis the amount and quality of cloth he would produce, the work of women workers could vary significantly from one week to the next. Carding, spinning, and winding, all jobs done by women, were especially susceptible to variation. Their variability resulted, to some extent, from the different qualities of cotton cloth used for calicoes.

Early Modern Artisans", in Geoffrey Crossick (ed.), The Artisan and the European Town, I5001900 (Aldershot, 1997), pp. 56-74; Patrick Joyce, "The Historical Meanings of Work: An Introduction", in Patrick Joyce (ed.), Historical Meanings of Work (Cambridge etc., 1987), pp. I-30; Michael Sonenscher, "Journeymen's Migrations and Workshop Organization in Eighteenth-Century France", in Steven L. Kaplan and Cynthia J. Koepp (eds), Work in France: Representations, Meaning, Organization, and Practice (Ithaca, NY etc., 1986), pp. 74-94.

25. Marta Vicente-Valentín, "Mujeres artesanas en la Barcelona moderna", in I. Pérez et al. (eds), Las mujeres en el Antiguo Régimen (Barcelona, 1994), pp. 59-90, 6I.

26. Likewise, other members of a master's household not related by blood were expected to perform tasks according to their gender and age.

27. Sirés did not treat the work of all of his male workers as if it were regular and indispensable. Weavers, all of whom were men, also received payment by the piece, and their work varied much more than that of the pintadors and "men of the meadows". Nevertheless, the cotton cloths they made were crucial to Sirés's production of high-quality calicoes, and consequently, he paid them far better than he paid women. 


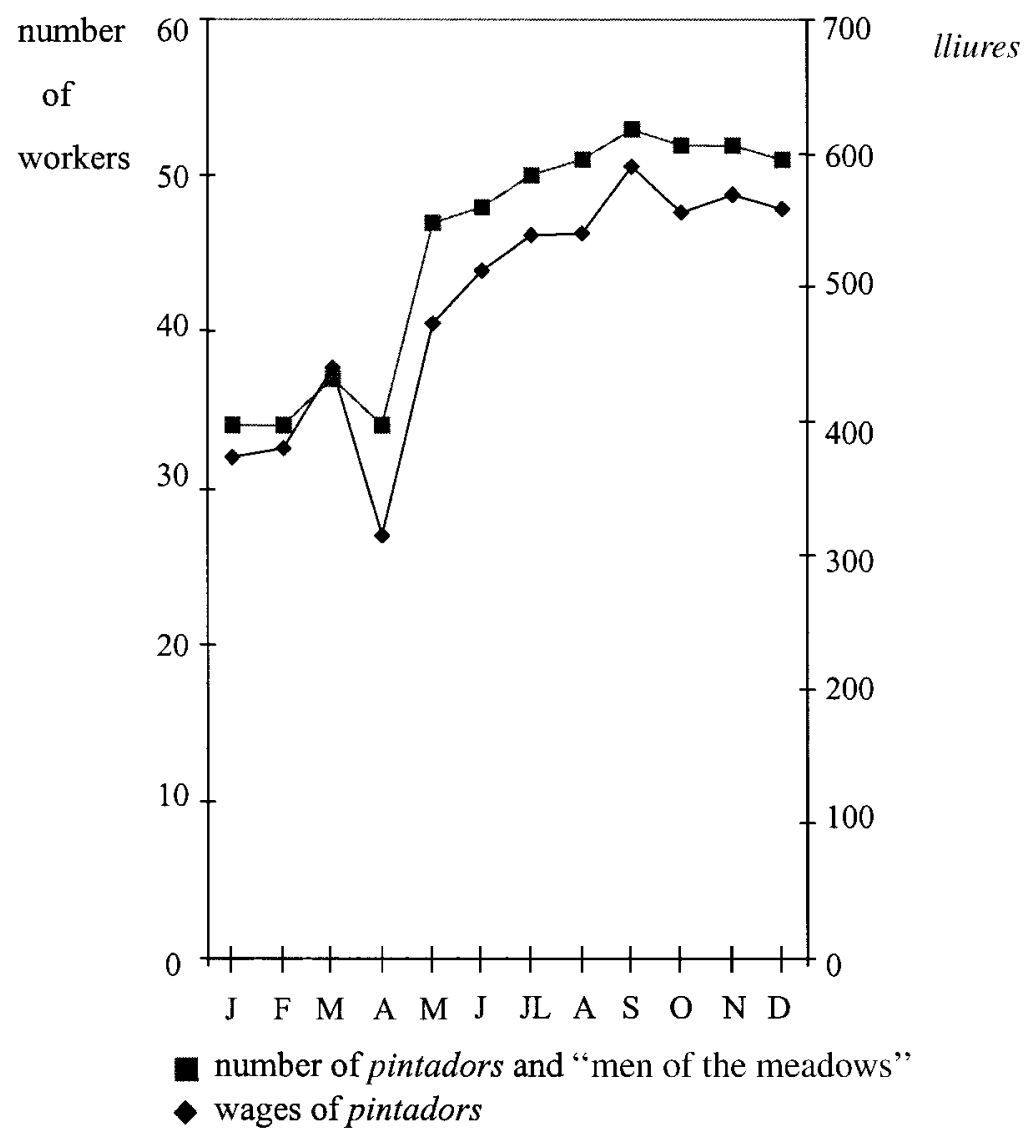

Figure 6. Number of Sirés's pintadors and "men of the meadows" and their wages in 1784 . AHCB: FC, B-24I through B-258.

Depending on the quality of the fabric, a cloth would need a greater or lesser number of threads and would require more or less work from carders, spinners, and winders. ${ }^{28}$ Therefore, it is not surprising to find that in 1782 winder Gregoria Dost wound only six pounds of thread during the week of 22-27 July, while the following week she increased her production to twenty-one pounds of thread. ${ }^{29}$

Sirés needed women's work in the factory to adapt to the needs of pintadors and "men of the meadows". Although the quality of the cloth was

28. For instance, it took one winder two days to wind the 1,300 threads in the warp of an inexpensive tretsena; in contrast, the more expensive disetsena, which had 1,700 threads, required the work of two winders for two days.

29. AHCB: FC, B-244, 22-27 July, 29 July-3 August: Book of salaries of the Sirés factory [hereafter, Book of salaries], 1782 . 


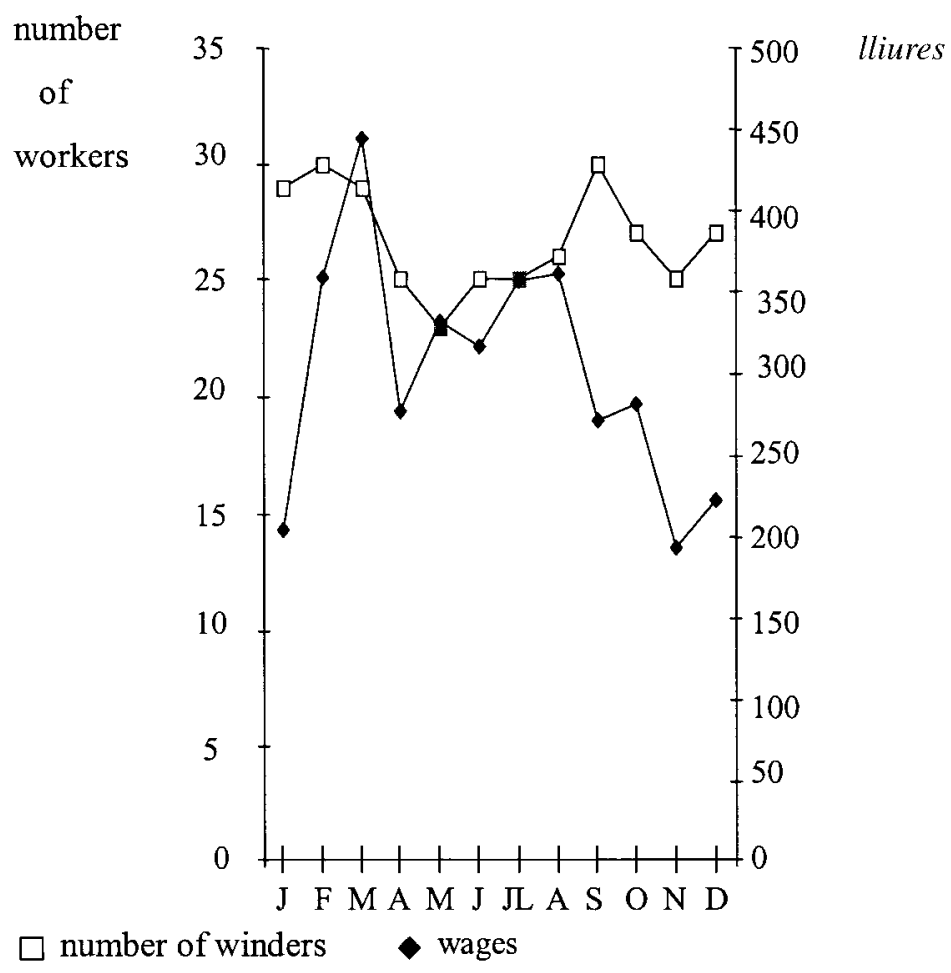

Figure 7. Number of winders and their wages in 1784 (divided per month with payments in lliures).

AHCB: $F C, B-24 I$ through $B-258$.

important, the price of calicoes depended above all on color and design. Therefore, Sirés made the work of pintadors and "men of the meadows" set the pace of production. If they needed more cloths, Sirés made carders, spinners, and winders work harder; if pintadors and "men of the meadows" had a backlog of calicoes to finish, women workers might be told to work less or go home. The salaried men worked continuously in the factory, whereas the women and child assistants worked only when Sirés needed them.

The factory owner paid carders, spinners and winders by the piece, whereas pintadors and "men of the meadows" received a fixed weekly salary. By paying them a salary, Sirés also ensured that they remained in the factory throughout the year, but since women workers only earned money based on what they produced, he did not have to keep them in the factory when they did not work.

Sirés not only hired women to carry out irregular and dispensable tasks; he also relied on boys, whose work consisted mostly of assisting other 
workers. Child assistants had to be versatile, as their work was extremely varied. Because assistants usually carried out very simple, repetitive, and easily learned tasks - such as helping pintadors spread the color on blocks, or carrying tools from one room to another - factory owners relocated them from one section of the factory to another as they thought it necessary. ${ }^{30}$ However, unlike the way he handled women workers, Sirés offered child assistants a fixed, though small, amount as payment. Sirés had child assistants in the factory at all times and their jobs, although easy to perform, were crucial to the production process. Boys ran back and forth from one room to another in the factory, picking up tools and handling small tasks.

Sirés assigned tasks with varying pay to women and children because families usually expected women and children to do whatever was necessary for their family to survive. This included having temporary and less stable jobs that would allow the master to continue working in the family shop. Sometimes the earnings from the master's trade did not meet all of his family's needs. In that case, the master's wife or children might have to seek additional work to supplement the family income. Traditionally, such extra work could include taking up other trades or working outside the home. In late eighteenth-century Barcelona, artisan children and women might also take up work in one of the city's calico factories.

Although variable, women's and children's factory work might represent a welcome relief to the family by allowing the master to continue working in the shop, even during periods of little activity when the family business might otherwise have been forced to fold. For instance, in 1780, women's earnings as winders in Sirés's factory ranged from a minimum of two sous to a maximum of thirty-two sous a week. ${ }^{31}$ The last amount could represent in some cases over half of the average income of an artisan family. Benita Carreras and her daughter Magdalena both worked for thirteen years as winders at the Sirés and other factories during the I78os. Magdalena alone earned about twenty-two sous weekly, which she gave to her mother. ${ }^{32}$ Meanwhile, Nicolás Carreras - Benita's husband and Magdalena's father worked at home, probably with the assistance of his son Francisco, also a weaver. Similarly, weaver Martí Barat worked at home while his wife and daughters labored in the Sirés factory winding cotton thread. ${ }^{33}$ In all these

30. For instance, in the Magarola factory, boys assisted the pintadors and the pencilers, who printed or penciled the calico designs on the cloths. Other boys prepared the cloth before a worker burnished it; see "Historia de la fábrica Magarola", in Diario curioso, erudito, económico y comercial, I9I (7 January 1787), copy in BC: Arxiu Gònima, 68/4.

3I. AHCB: FC, B-242: Book of salaries, I780.

32. AHCB: Arxiu del Veguer, XXXVII-I244, I796; AHCB: FC, B-246: Book of salaries, I784.

33. Arxiu de Santa Maria del Pi [hereafter, ASMP]: Comunions, 1787, carrer Trentaclaus 55: List of parishoners who took communion; AHCB: FC, B-24I through B-245: Book of salaries, I779I783; AHCB: FC, B-250: Book of salaries, I787. 
examples women's work in the factory represented an important addition to the household economy.

In artisan families with several children, the master artisan could send one or more of them to a calico factory to increase the family income. In I795, a testimony in a lawsuit observed how "many youngsters only eight or nine years old work in the calico factories and earn not only enough for themselves but to help their parents". ${ }^{34}$ For instance, in 1792, the three Notascos brothers worked as child assistants to Sirés's pintadors. Their combined earnings amounted to forty-eight sous per week, which was close to a factory weaver's salary of fifty-four sous. ${ }^{35}$ Yet a child's income alone was rarely high enough to support an entire family. The child assistants in Sirés's factory earned an average of nineteen sous per week in $1795 .{ }^{36}$ This small amount represented less than a third of the average household income, but many families found even this small amount useful. ${ }^{37}$

The work of children and women not only helped calico factories and artisan families survive, it also allowed factories and artisan workshops to complement each other. Just as Sirés sought workers willing to labor at different times by the piece or for low wages, artisan families might be willing to have their women and children earn an additional income, even if a modest one. In addition, neither Sirés nor master artisans might want their women and children to work full time and year round in the factory. Masters also faced constant ups and downs in their production. When production was down they were likely to send some of their family members to work for wages in a calico factory. However, it was just as likely that they would recall a family member from factory work whenever their businesses picked up. This may not always have suited the factory owners' requirements. I will examine this situation in the next section and discuss what Sirés did to find a solution - and thereby to secure continuity in his factory's production.

\section{FAMILY AND FACTORY WORK: CONFLICTING LOYALTIES FOR SIRÉS'S WORKERS}

Family and factory work sometimes resulted in conflicting loyalties for workers, and one of Sirés's greatest challenges was to find ways to balance them in order to keep his factory afloat. A good example of such a conflict took place during the week of I2-I7 July I784. It was a busy week at his factory during the usually active summer season, when calicoes could be dried

34. Arxiu de la Corona d'Aragó [hereafter, ACA]: Reial Audiència [hereafter, RA], plets civils, n. I092, Rosa Coll versus Domingo Crous, 1793.

35. AHCB: FC, B-253: Book of salaries, 1792.

36. AHCB: FC, B-257: Book of salaries, I795.

37. For an example of the average of a household income, see Arxiu Diocesà de Barcelona: Processos,

n. 334 bis: Divorce suit of Paula Padres and the carpenter Marco Padres, I792. 
quickly in the fields under the hot sun. But in the middle of the week, apparently without previous notice, Isabel Burgada left her place at the factory as a winder. The book of salaries for that year does not indicate the reason for her action. Perhaps she had to care for a sick relative or decided to work in another factory or workshop. Whatever the reasons, her sudden departure could not have come at a worse time for Sirés. Since other factories were probably also working at full capacity, locating a spare winder was not easy. In fact, it took Sirés a whole week to find a replacement for Burgada. In the meantime, he had to increase the workload of his remaining twenty-three winders. ${ }^{38}$ Such unpredictable behavior on the part of factory workers caused repeated difficulties to Barcelona's calico factory owners in the late eighteenth century.

One way Sirés tried to discourage workers from leaving his factory was by allowing employees to live and work in the factory alongside their family members. Sirés's factory building on carrer Trentaclaus was large enough to house twenty workers and their families - in all, about forty men, women, and children (Figure I). ${ }^{39}$ Sirés and the foreman of the weavers lived in separate rooms adjacent to the weavers' room. Other families lived in rooms located on different floors. For instance, the Dost family had their quarters next to the pintadors' room. This family had three members, all of whom worked for Sirés. Gregoria Dost was a winder, her husband, Manuel, was a "man of the meadow", and their son Josep worked as a pintador. The Dosts shared kitchen facilities and a well with other families living in the factory. The factory even had a chapel, where workers and their families could pray together on Sundays and holidays. Other calico factories in Barcelona offered housing arrangements like Sirés's. For instance, Esteve Canals had living accommodations for workers in his factory building. ${ }^{40}$ Likewise, the Magarola factory provided housing to its foremen, their families, and other factory workers. ${ }^{4}$

It seems that Sirés encouraged his workers to live in the factory in order to have a reliable source of labor under his close supervision. Although Sirés himself did not explain why he provided rooms for his workers, statements from other factory owners point to several possible motivations. In I789 factory owner Juan Costa y Merla explained that he had his workers live with their families next to the factory building on carrer Estruc in the hope that they would be "on time to work"; he also wanted to "have them avail-

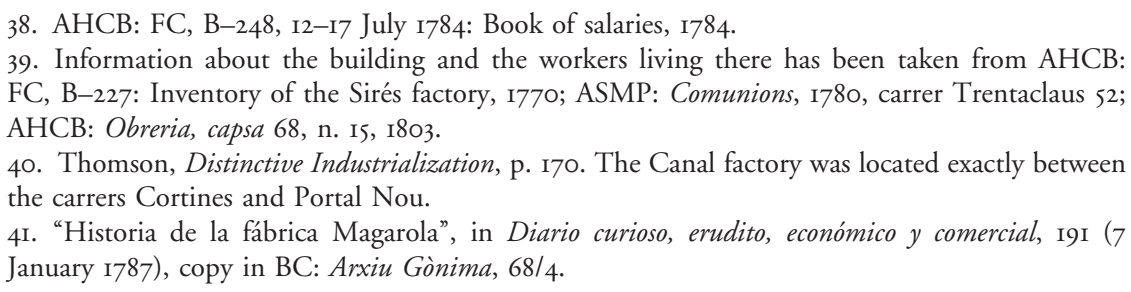


able whenever he needed them". ${ }^{42}$ Contemporary English factory owners also offered free lodging or low rents in factory-owned buildings to their workforce. ${ }^{43}$

The housing arrangement Sirés and other factory owners offered to their workers resembled the way artisans coped with family and work demands, turning workplace and home into inseparable spaces. In cities such as Paris, Vienna, and Barcelona, the overlap of working and domestic spaces translated into a participation of all household members in the artisan trade, allowing great flexibility of work, especially to women. ${ }^{44}$ Artisan women could attend their work at the spinning wheel or winding device while taking care of infants. Moreover, in the artisan shop, mothers could train daughters or young relatives in their trade while attending to domestic tasks. For instance, in 1785 Barcelona chronicler Rafel Amat described the way a female acquaintance, La Pona Maioles, taught needlework to ten pupils, some of whom were her relatives. She taught in the kitchen, where she could combine her teaching and cooking. ${ }^{45}$

Just as in the case of La Pona, artisan family members also labored alongside each other in the Sirés factory, and many of them did it with relatives. Sirés seems to have preferred to give work to relatives of his employees. At least thirty-nine per cent of Sirés's workers had family ties with co-workers. Additional entries in the book of salaries of individuals with the same family name, but without proven family ties, suggest that the percentage may have been higher. A clear case of Sirés's apparent predilection for hiring relatives is the Molins family. In 1779, Sirés hired Baltasar Molins, who was nine at the time. The next year Sirés hired Baltasar's younger brother, Carlos, who also began to work at the age of nine. Then, in 1782, the father of the two children, Antón, came to work in the factory as pintador; two years later, their mother, Teresa, became a Sirés winder. In 1785, Raymunda, the twenty-five-year-old sister of Baltasar and Carlos, also started to work for Sirés, along with her new husband, Joan Font, a linen weaver. The Molins also had other relatives in the factory: Andreu Molins, probably Antón's brother, and Andreu Molins's two sons, Esteve and Joan. ${ }^{46}$

42. AHCB: Arxiu del Veguer, XXXVII-I494, I789.

43. See Stanley D. Chapman, The Early Factory Masters: The Transition to the Factory System in the Midlands Textile Industry (Newton Abbot, 1967), pp. 159-174.

44. See Josef Ehmer, "Family and Business in the Upper and Lower Middle Classes in Eighteenth and Nineteenth-Century Vienna", (presented at the Seminar on Family Enterprise and Small Commodity Production, Wilmington, DL, April I994; cited with the author's permission); Xavier Lencina Pérez, "Activitat laboral i espai familiar en els gremis barcelonins de l'època moderna", in Tercer Congrès d'Història Moderna de Catalunya: Actes, special number of Pedralbes, 2 vols (Barcelona, 1984), 2, pp. 335-34I; Sonenscher, "Journeymen's Migrations".

45. Rafel d'Amat i de Cortada, Calaix de Sastre, 8 vols, Ramon Boixareu (ed.), (Barcelona, 1988), I, Pp. I43-I45.

46. AHCB: FC, B-24I through B-249: Book of salaries, I779-I786; for Baltasar's age; see ASMP: Obits (deceased), April II, I8I5; for Raymunda's age and marriage; see Arxiu dels Sants Just i Pastor 
Sirés also allowed workers to train younger relatives who might later become his workers. Just as in the workshop, parents could teach their children the skills they used in the factory. ${ }^{47}$ For instance, Maria Anna Brugada wound thread into weft bobbins while her mother Josefa warped the thread to set in the loom. ${ }^{48}$ Similarly, in 1779, eight-year-old German Marquillas became a child assistant to his father Francisco, a pintador in the factory. ${ }^{49}$ In another example, ten-year-old Coloma Barat received her training on how to wind thread from her mother in the factory. Coloma became a winder in her own right and stayed in the factory for seven years until she moved out of her parents' house, probably to marry and establish a separate household..$^{\text {so }}$

Sirés further reinforced the family work in the factory by allowing workers to have relatives substitute for them. Thus, when one family member could not attend to his or her duties in the factory, another member would take his or her place. Siblings, husbands and wives, mothers and daughters, or simply close relatives exchanged places in the factory on a regular basis. ${ }^{\text {SI }}$ For example, in 1779, Antón Sallents worked from I January to Io January in Sirés's factory as a child assistant. On Io January, Agustí, another member of the Sallents family, took his place until io April. Agustí then left the factory, only to have his place taken by another young relative. Fifteen days later, on 25 April, Antón, the first of the Sallents to work for Sirés, returned to the factory for two weeks. On the same day he left, another family member, Joan Sallents, took Antón's job until to May. ${ }^{52}$ This kind of job sharing was not unusual.

It appears that by having workers live in the factory, by hiring several family members, by allowing workers to have relatives substitute for them, or by training children who might one day replace their parents, Sirés may

[hereafter ASSJP]: Matrimonis (matrimonies), 9 July 1785; for Carlos's age; see ASSJP: Comunions, 1787, carrer Trentaclaus n. 44.

47. This was also the case in eighteenth-century calico manufactures of north-western France; see Pierre Caspard, "Calico Painters", p. II2.

48. AHCB: FC, B-246: Book of salaries, 1784 .

49. AHCB: FC, B-24I: Book of salaries, I779.

50. AHCB: FC, B-250 through B-257: Book of salaries, 1787-1795. For Coloma's age; see ASMP: Comunions, 1790, carrer Trentaclaus n. 55. For Coloma's marriage; see ASMP: Comunions, 1796, carrer Trentaclaus n. 55, segon pis.

5I. The recruitment of workers' relatives or even entire families was characteristic of textile factories in eighteenth- and nineteenth-century England and France; see Michael Anderson, Family Structure in Nineteenth-Century Lancashire (Cambridge etc., I97I), pp. II2-I23; William Reddy, "Family and Factory: French Linen Weavers in the Belle Epoque", Journal of Social History, 8 (1975), pp. I02-II2; Neil Smelser, Social Change in the Industrial Revolution: An Application of Theory to the Lancashire Cotton Industry, 1770-I840 (London etc., 1959), pp. 186-I93; Andrew Ure, Philosophy of Manufactures (London, I835), pp. 277-404.

52. In 1783 , one of the brothers, Agustí, returned to work in the factory as a "man of the meadows". In 1784, he became pintador and stayed in the factory until I79I. AHCB: FC, B-245 through B-253: Book of salaries, I783-1792. 
have been trying to prevent sudden vacancies from interrupting the work schedule. Sirés may have also hoped that by providing a "familiar" context for workers, he could make them loyal or dependent on him and his factory.

However, it would be a mistake to equate the factory with a family, despite the numerous parallels between the factory's organization of work and that of the artisan family. The factory did not comprise one family but brought together many. Even workers who lived and worked in the factory building sometimes came with their own families. The artisan family expected its members to coordinate their work for the benefit of their household; Sirés expected his employees to work for the benefit of his factory. This resulted in conflicting loyalties for the factory workers, since many artisan families treated factory work as complementary to what they saw as their most important aim, namely, to keep their own workshops in business and to ensure their families' wellbeing. In the end, Sirés may have tried to ease the tensions between the needs of the factory and those of his workers' families by trying to incorporate numerous aspects of the way artisan families lived and worked into the factory. Nevertheless, the tensions probably never disappeared altogether.

\section{CONCLUSION}

This article has illustrated the way a factory owner replicated artisan forms of organizing work to ease a conflictive relationship between his factory's requirements for production and the needs of the workforce until the midI790s. However, in 1796 a drastic economic change forced Sirés to reorganize his production. In that year Spain and England went to war. The conflict dealt a severe blow not only to the Sirés calico factory but to the Catalan textile industry as a whole..$^{53}$ The war made trade increasingly difficult for merchants and factory owners. Clients drastically reduced their orders for calicoes, while factory owners were not able to obtain adequate supplies of raw materials. During the first phase of the Anglo-Spanish war, which lasted from 1796 to I80I, factories dramatically reduced production. ${ }^{54}$ At first, the English blockade, which effectively cut commercial ties between Spain and its American colonies, did not have a pronounced effect on production in the Sirés factory. In 1796, Sirés's sales still amounted to an impressive 130,000 lliures. By 1799, sales however had fallen thirty-eight per cent as compared with $1796 .{ }^{5}$ Other factories were harder hit. The Rull

53. For the general situation of the calico industry, see Thomson, Distinctive Industrialization, pp. 268-30I, 359-360.

54. Josep Maria Delgado, "El impacto de las crisis coloniales en la economía catalana (I787I807)", in Josep Fontana (ed.), L'economía española al final del Antiguo Régimen, 4 vols (Madrid, I982), 3, pp. 99-I69.

55. AHCB: FC, B-283 and B-284: Account books, 1796, 1799 . 
calico factory saw a seventy per cent decrease in sales between 1796 and $1797 .^{56}$

In trying to find solutions for this new situation, Sirés again resorted to the artisan workshop. This time, he subcontracted artisans working in their shops; there artisans produced most of the white cotton cloth the factory needed and in some cases even dyed the factory's calicoes. This meant savings mainly in wages. In such difficult times, Sirés kept a minimum workforce of between fifty and sixty workers in the factory (Figure 3). Among them we find pintadors, "men of the meadows", a few child assistants and engravers, and a head of the weavers, who was probably in charge of sending out the material to the weavers working for the factory in their workshops. Sirés, however, did not altogether stop benefiting from the flexible and cheap work of women. Among the engravers of the factory during the I790s were two women engravers. Women engraved blocks with pins. Instead of using the chisel more characteristic of the work of male engravers, women engravers hammered the pins on to old patterned blocks to modify the design inexpensively. Sirés probably found this was a quick and less expensive way of keeping up with the variable world of calico fashion, a solution that was also common among French manufacturers. ${ }^{57}$ Other factory owners in Barcelona used women engravers to modify old patterned blocks, as they tried to cope with the general economic downturn caused by the seemingly endless wars in Europe and the Atlantic basin as well as by aggressive competition from foreign textile manufacturers. ${ }^{58}$

Although Sirés continued to decentralize production, economic circumstances worsened. In I808, the same year that the war with England came to an end, French troops invaded Spain, entering Barcelona on 9 February. The first three years of foreign occupation proved disastrous to Barcelona's industries. For Sirés the French invasion meant a drastic reduction in the factory's already small production. Around 18I4, the factory went bankrupt. Sirés finally shut down his factory in 1816.

The Sirés case is not just an example of how a factory owner adapted traditional ways of organizing work to new circumstances. It also shows how the early process of industrialization did not inevitably lead to conflict between the needs of artisan families and those of calico factories. In fact, factory owners followed an artisan model when organizing flexible work strategies. First, early factory owners such as Sirés replicated and adapted artisan practices of work, such as the gender and age division of work and laboring alongside family members, to the new environment of the factory.

56. Alejandro Sánchez, "L'estructura comercial d'una fabrica d'indianes barcelonina: Joan Rull i Cia. (1790-182I)", Recerques, 22 (1989), pp. 75-105, 19.

57. Caspard, "Calico Painters", pp. I08-I34.

58. For the large Gònima factory and the reduction of its workforce during the 1790s, see BC: Arxiu Gònima, 33/3, salaries of the factory, I790s. On the rising number of unemployed workers, see Diario de Barcelona, 28 October I80o; copy in BC: Arxiu Gònima, 68/4. 
Second, artisan families working in the factory did not have to give up their own workshops. In fact, artisans might have used factory work as a means of earning extra income to help the family workshop get over difficult periods. A lull in work at home could be made up by sending family members to work in a factory.

In Barcelona, the calico industry of the I820s gradually returned to prewar levels of production. By that time, however, the Sirés factory had shut down production. A new generation of workers, perhaps with fewer artisan links, filled the cotton factories. Although the economic crises from 1796 on marked a watershed in the history of Barcelona's calico industry, it remains unclear whether nineteenth-century factories still retained the artisan basis that helped earlier factory owners to run their enterprises successfully. William Sewell and John Rule have argued, for France and England respectively, that workers in nineteenth-century factories were the heirs of eighteenth-century artisans and their social and labor organizations. ${ }^{99}$ However, more work needs to be done on how division of work and production in the factory replicated traditional artisanal practices of work in the nineteenth century. Recent studies have found that nineteenth-century owners may have tried to adapt their forms of payment and hiring to the needs of their workers, some of whom owned thriving artisan workshops. ${ }^{60}$ Therefore, it is likely that family needs were still a powerful element in the way artisans treated factory work well into the nineteenth century.

59. John Rule, "Against Innovation? Custom and Resistance in the Workplace, 1700-1850", in Tim Harris (ed.), Popular Culture in England, c. I500-I850 (New York, 1995), pp. I68-I88; William H. Sewell, Work and Revolution in France: The Language of Labor from the Old Regime to 1848 (Cambridge etc., I980), pp. I62-193; see also Friedrich Lenger, "Beyond Exceptionalism: Notes on the Artisanal Phase of the Labour Movement in France, England, Germany and the United States", International Review of Social History, 36 (1991), pp. I-23.

6o. Enriqueta Camps, La formación del mercado de trabajo industrial en la Cataluña del siglo XIX (Madrid, 1995), pp. 19I-215; Gràcia Dorel-Ferré, Les colònies industrials a Catalunya (Barcelona, 1992), pp. 205-270; Albert Garcia Balañà, "Sistemas de trabajo y acceso a la fábrica en la primera algodonería catalana. Algunas evidencias comparativas sobre políticas familiares, patronales y sindicales en la hilatura mecánica (I84I-I870)", (presented at the Family Strategies Workshop, Universitat Pompeu Fabra, Barcelona, April 1997; cited with the author's permission). 
